WCH-374

Rev. 0

River Corridor Closure Contract

\title{
300 Area D4 Project Fiscal Year 2009 Building Completion Report
}

\section{January 2010}

For Public Release

\section{Washington Closure Hanford}


TRADEMARK DISCLAIMER

Reference herein to any specific commercial product, process, or service by trade name, trademark, manufacturer, or otherwise, does not necessarily constitute or imply its endorsement, recommendation, or favoring by the United States Government or any agency thereof or its contractors or subcontractors.

This report has been reproduced from the best available copy.

Printed in the United States of America 


\section{STANDARD APPROVAL PAGE}

Title:

Author Name: B. J. Skwarek

Approval: $\quad$ L. M. Douglas, Project Engineer
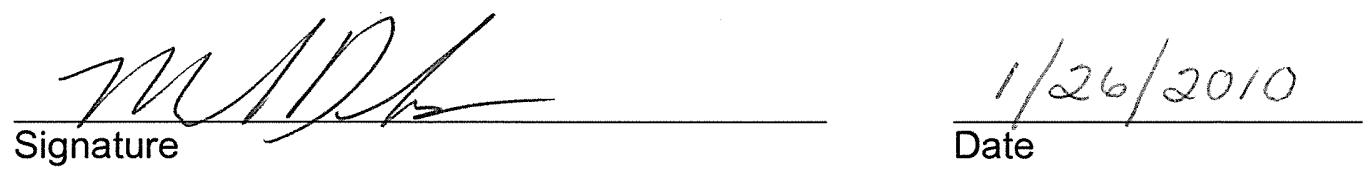

The approval signature on this page indicates that this document has been authorized for information release to the public through appropriate channels. No other forms or signatures are required to document this information release. 
WCH-374

Rev. 0

\section{River Corridor Closure Contract}

\section{Area D4 Project Fiscal Year 2009 Building Completion Report}

January 2010

Author:

B. J. Skwarek

WorleyParsons Polestar

For Public Release 


\section{TABLE OF CONTENTS}

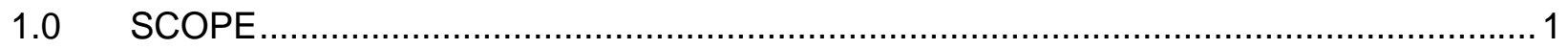

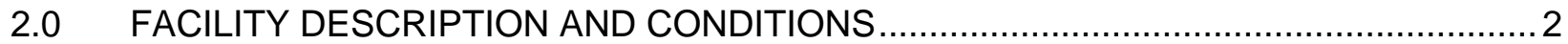

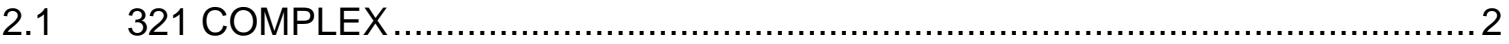

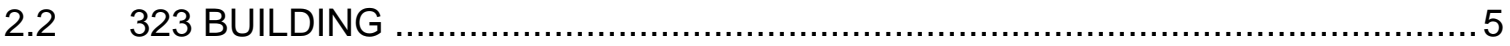

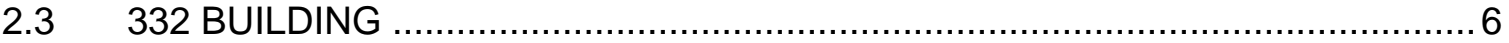

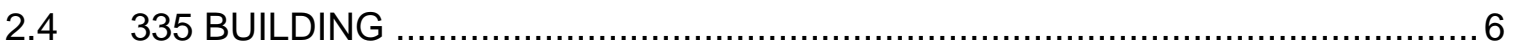

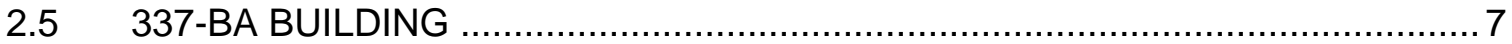

2.6 3621-66 UNDERGROUND STORAGE TANK ............................................. 8

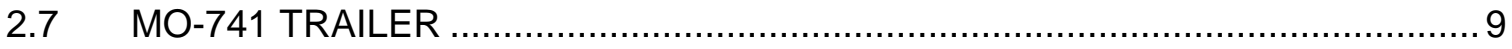

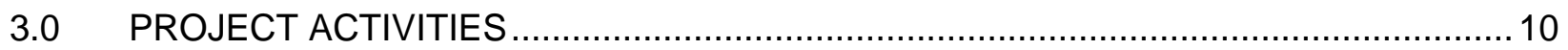

B.1 ENGINEERING AND PERMITS ......................................................... 10

3.2 HAZARDOUS MATERIAL REMOVAL .................................................. 11

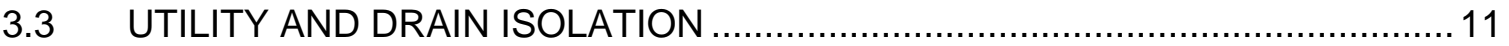

3.4 DEMOLITION OF ABOVE-GRADE STRUCTURES ..................................... 11

3.5 BELOW-GRADE DEMOLITION AND SITE RESTORATION........................... 12

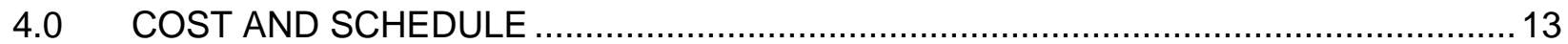

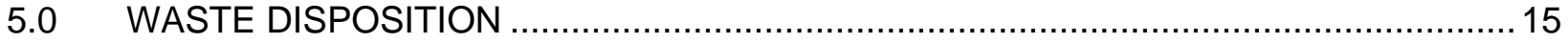

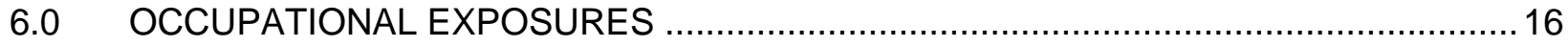

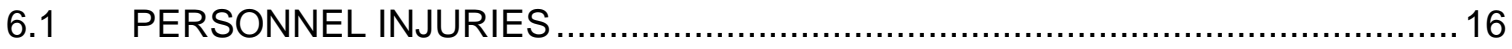

6.2 PERSONNEL RADIOLOGICAL EXPOSURES .......................................... 16

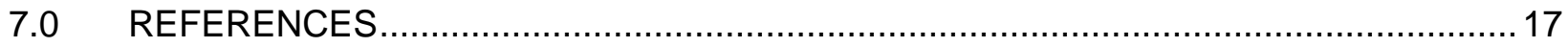




\section{FIGURES}

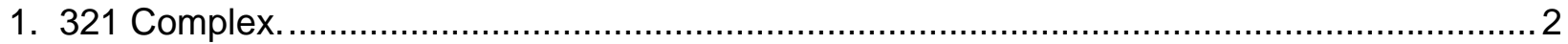

2. The 321 Complex was Turned Over to WCH in September 2005................................ 3

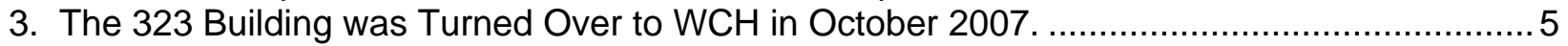

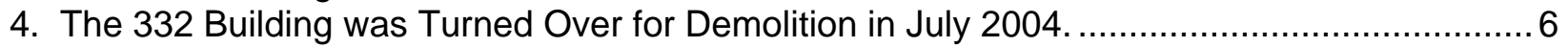

5. The 335 Building was Turned Over for Demolition in September 2005........................... 7

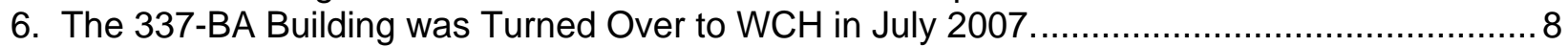

7. The 3621-66 Underground Storage Tank was Turned Over to WCH in August 2005.......... 8

8. The MO-741 Mobile Building was Turned Over to $\mathrm{WCH}$ for Demolition in

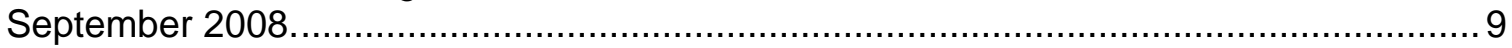

\section{TABLES}

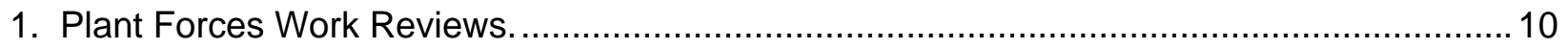

2. Initial Hazard Categorization Evaluations and Results. ............................................. 11

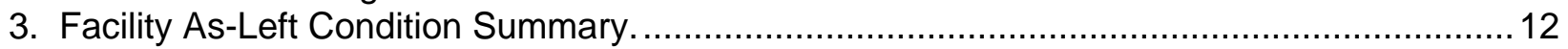

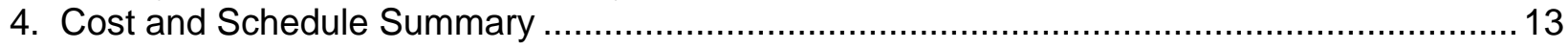

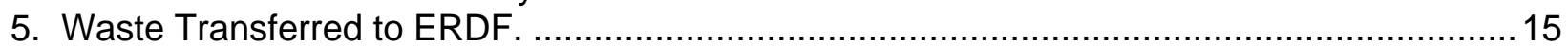




\section{METRIC CONVERSION CHART}

\begin{tabular}{|c|c|c|c|c|c|}
\hline \multicolumn{3}{|c|}{ Into Metric Units } & \multicolumn{3}{|c|}{ Out of Metric Units } \\
\hline If You Know & Multiply By & To Get & If You Know & Multiply By & To Get \\
\hline Length & & & Length & & \\
\hline inches & 25.4 & millimeters & millimeters & 0.039 & inches \\
\hline inches & 2.54 & centimeters & centimeters & 0.394 & inches \\
\hline feet & 0.305 & meters & meters & 3.281 & feet \\
\hline yards & 0.914 & meters & meters & 1.094 & yards \\
\hline miles & 1.609 & kilometers & kilometers & 0.621 & miles \\
\hline Area & & & Area & & \\
\hline Sq. inches & 6.452 & sq. centimeters & sq. centimeters & 0.155 & sq. inches \\
\hline sq. feet & 0.093 & sq. meters & sq. meters & 10.76 & sq. feet \\
\hline sq. yards & 0.836 & sq. meters & sq. meters & 1.196 & sq. yards \\
\hline sq. miles & 2.6 & sq. kilometers & sq. kilometers & 0.4 & sq. miles \\
\hline acres & 0.405 & hectares & hectares & 2.47 & acres \\
\hline Mass (weight) & & & Mass (weight) & & \\
\hline ounces & 28.35 & grams & grams & 0.035 & ounces \\
\hline pounds & 0.454 & kilograms & kilograms & 2.205 & pounds \\
\hline Ton & 0.907 & metric ton & metric ton & 1.102 & ton \\
\hline Volume & & & Volume & & \\
\hline teaspoons & 5 & milliliters & milliliters & 0.033 & fluid ounces \\
\hline tablespoons & 15 & milliliters & liters & 2.1 & pints \\
\hline fluid ounces & 30 & milliliters & liters & 1.057 & quarts \\
\hline cups & 0.24 & liters & liters & 0.264 & gallons \\
\hline pints & 0.47 & liters & cubic meters & 35.315 & cubic feet \\
\hline quarts & 0.95 & liters & cubic meters & 1.308 & cubic yards \\
\hline gallons & 3.8 & liters & & & \\
\hline cubic feet & 0.028 & cubic meters & & & \\
\hline cubic yards & 0.765 & cubic meters & & & \\
\hline Temperature & & & Temperature & & \\
\hline Fahrenheit & $\begin{array}{l}\text { subtract } 32 \text {, } \\
\text { then } \\
\text { multiply by } \\
5 / 9\end{array}$ & Celsius & Celsius & $\begin{array}{l}\text { multiply by } \\
9 / 5, \text { then } \\
\text { add } 32\end{array}$ & Fahrenheit \\
\hline $\begin{array}{l}\text { Radioactivity } \\
\text { picocuries }\end{array}$ & 37 & millibecquerel & $\begin{array}{l}\text { Radioactivity } \\
\text { millibecquerels }\end{array}$ & 0.027 & picocuries \\
\hline
\end{tabular}




\subsection{SCOPE}

This report summarizes the deactivation, decontamination, decommissioning, and demolition (D4) activities of seven facilities in the 300 Area of the Hanford Site in fiscal year (FY) 2009. These facilities include:

1. 321 Complex $(321,321 B, 321 \mathrm{C}, 321 \mathrm{D})$

2. 323 Building (Formerly 321A)

3. 332 Building

4. 335 Building

5. 337-BA (Boiler Annex) Building

6. 3621-66 Underground Storage Tank

7. MO-741 Trailer.

The D4 of these facilities included characterization; engineering; removal of hazardous and radiologically contaminated materials; equipment removal; utility disconnection; deactivation, decontamination, demolition of the structure; and stabilization (in-place) or removal of slabs and foundations.

This report also summarizes in Section 3 the nine below-grade slabs/foundations removed in FY09 of buildings demolished in previous fiscal years. 


\subsection{FACILITY DESCRIPTION AND CONDITIONS}

The seven facilities detailed in this report were located in the 300 Area of the Hanford Site, which is owned and operated by the U.S. Department of Energy (DOE), in Benton County, Washington. The 300 Area was constructed and operated as a reactor fuel fabrication and laboratory complex.

\subsection{COMPLEX}

The 321 complex includes buildings 321, 321B, 321C, 321D, and 323 (formerly 321A).

Figure 1. 321 Complex.

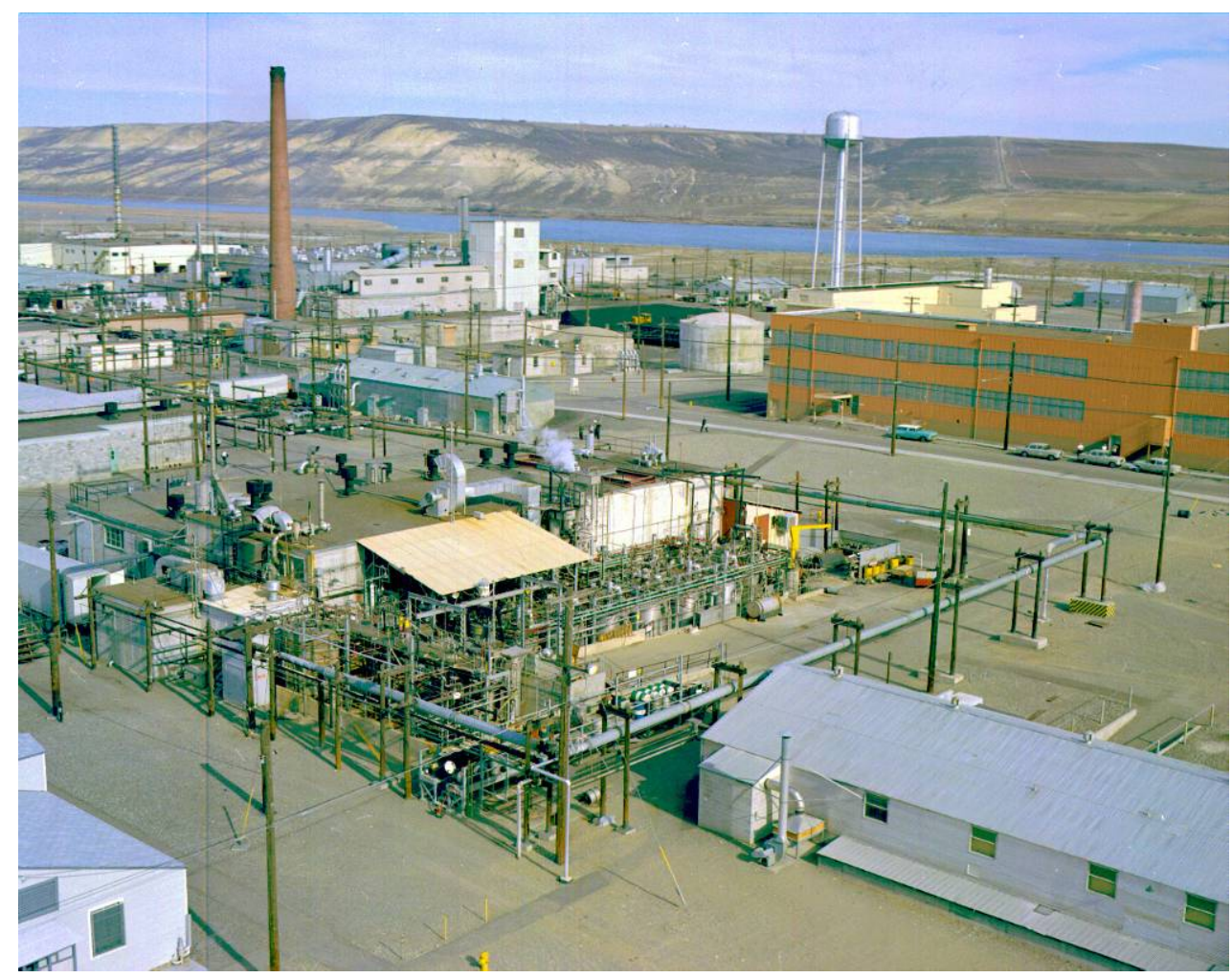

The 321 Cold Chemical Semi-Works, also known as the 321 Separations Building, provided chemical pilot plant support for the 200 Area chemical separations plants from 1944 to 1967. In 1967, the 321 Buildings were cleaned out and modified to install the Hydraulic Core Mockup (HCM) pilot plant systems for the Fast Flux Test Facility (FFTF) Reactor project.

The 321 Building Tank Farms 1 and 2 on the south side were replaced by the 321B Test Loop Facility and the 321C Inlet Plenum Module Demonstration Unit, respectively. The 321 Maintenance Shop (east side) was replaced by the 321D Seismic Facility. 


\section{Figure 2. The 321 Complex was Turned Over to WCH in September 2005.}

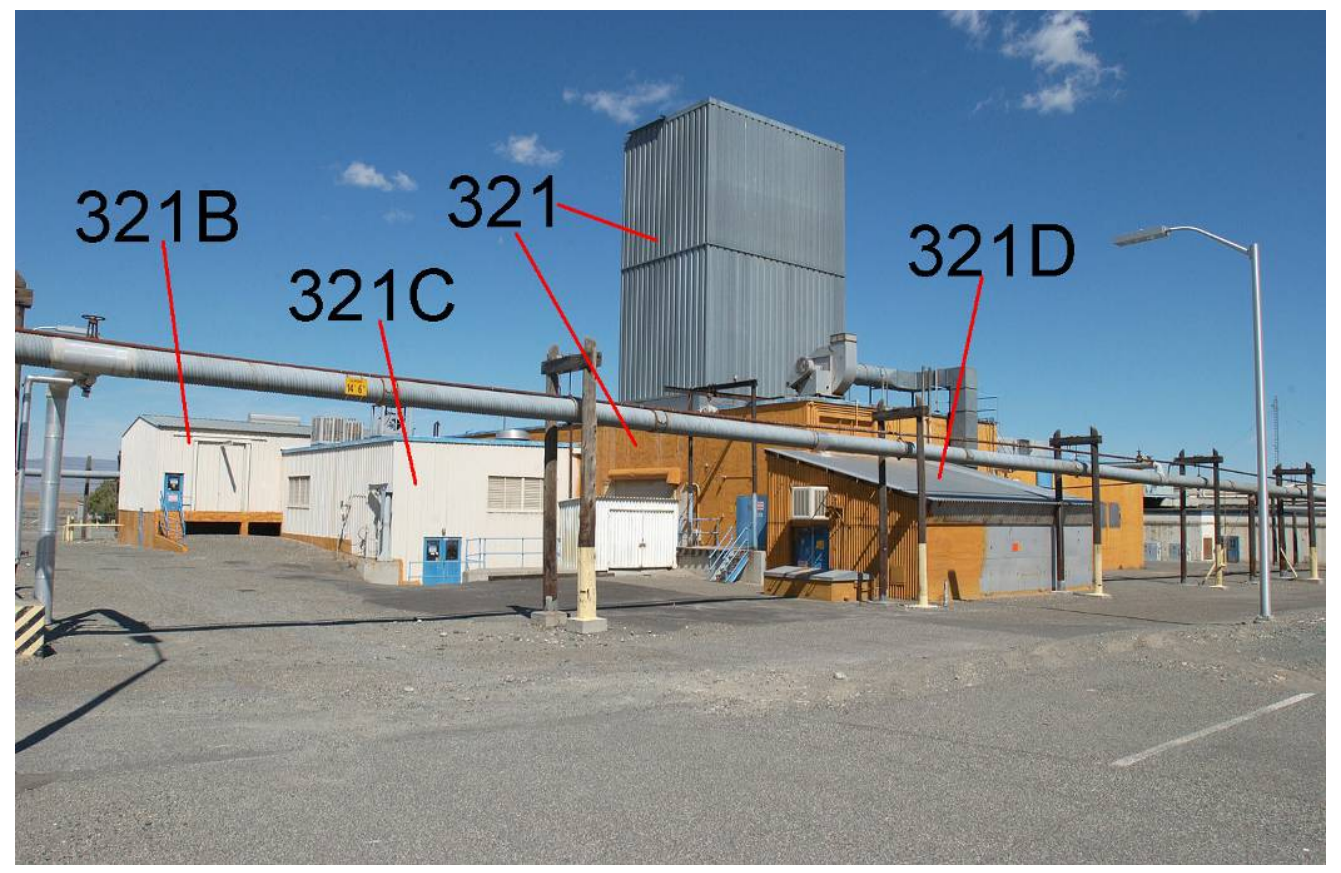

Since 1995, the 321, 321B, 321C, and 321D Buildings had been designated as restricted access, contaminated (e.g., biological, chemical, and radiological) facilities in a cold, dark, and isolated status.

321 Building: The 321 Building was partitioned about mid-length with an east-west 0.3-m (1-ft)

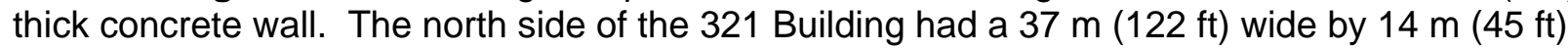

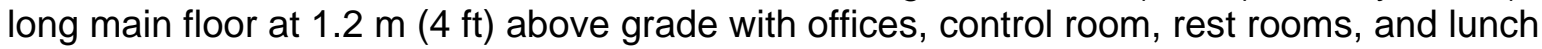
room. The north side had a full basement with ventilation supply, equipment, maintenance, and storage rooms on a concrete floor at $2.3 \mathrm{~m}(7.5 \mathrm{ft})$ below grade and a concrete roof at $5.5 \mathrm{~m}$ $(18 \mathrm{ft})$ above grade. Two rooms on the north wall (center and east end) had 0.3-m (1- $\mathrm{ft}$ ) thick concrete walls.

The south side of the 321 Building was a $37 \mathrm{~m}$ (122 ft) long by $18.1 \mathrm{~m}(59.5 \mathrm{ft})$ wide, high bay structure with multiple basements, steel grate mezzanines, and a steel framework tower

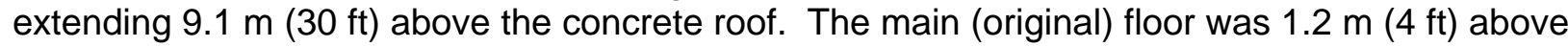
grade; the main basement floor (original) was $2.3 \mathrm{~m}(7.5 \mathrm{ft})$ below grade. After 1967, a

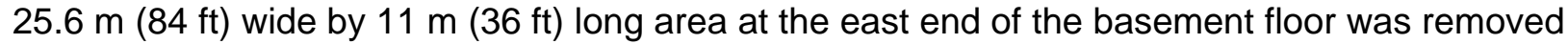

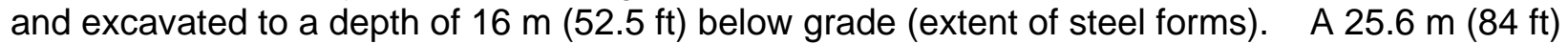

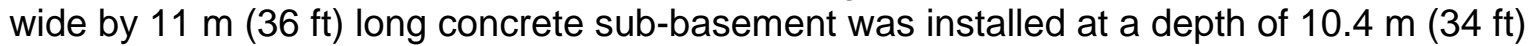
below grade. A steel framework structure was installed in the sub-basement to support metal

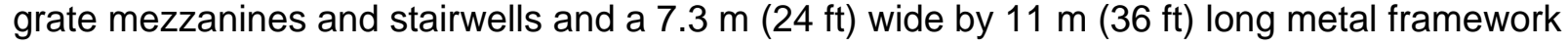
tower extending through the south roof $(7 \mathrm{~m}$ [23.1 ft] above grade) to a height of $16.2 \mathrm{~m} \mathrm{(53.1 \textrm {ft } )}$ above grade. The tower was located in the east end of the sub-basement over a $6.1 \mathrm{~m}(20 \mathrm{ft})$ diameter by $2.7 \mathrm{~m}(9 \mathrm{ft})$ deep concrete pit. The floor of the concrete pit was $13.2 \mathrm{~m}(43.5 \mathrm{ft})$ below grade. The top of the HCM of the FFTF Reactor installed in the concrete pit was at

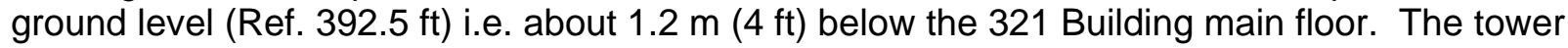




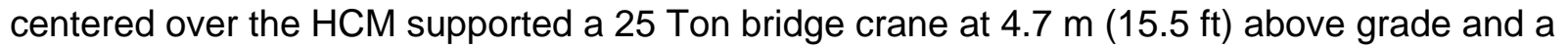
smaller circular monorail crane at $14.9 \mathrm{~m}$ (49 ft) above grade.

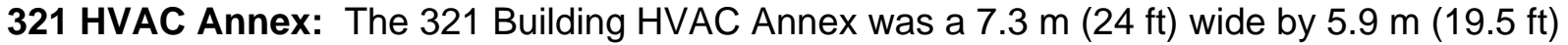

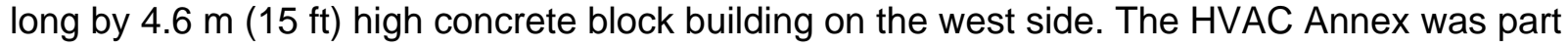
of the original building construction and had a built-up composition roof.

321 Equipment Vent/Battery Room Annex: The 321 Building Equipment Vent and Battery

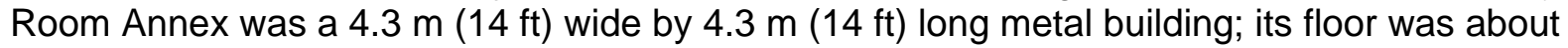

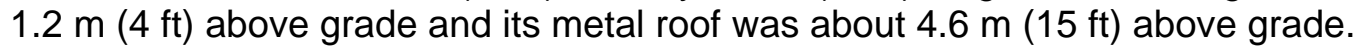

321B Building Test Loop (321 Tank Farm No. 1): The 321B Building was a $15 \mathrm{~m}$ (50 ft) long

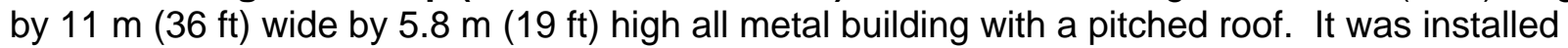
on top of the concrete containment walls of the 321 Tank Farm No. 1 that varied in height from

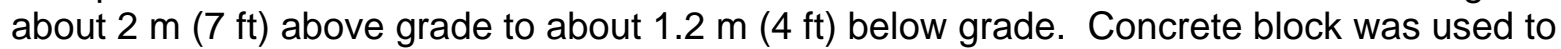
level the tank farm containment wall. The metal east wall of the 321B Building forms the west wall of the 321C Building that was installed over the adjoining 321 Tank Farm No. 2. The concrete basement of the 321B Building included a concrete sump (approximately $1.2 \mathrm{~m} \mathrm{[4} \mathrm{ft}$ ]

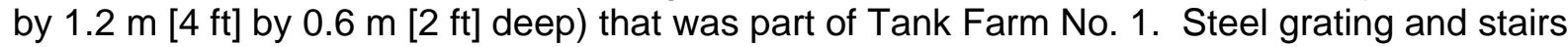
connected the main level of the 321B Building to the basement area.

321C Building HCM Pump House (321 Tank Farm No. 2): The 321C Building was a

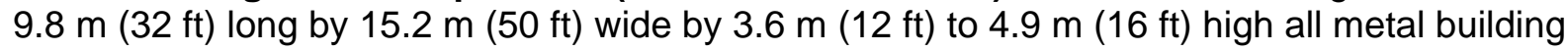
with a flat roof. It was installed on the concrete containment walls of 321 Tank Farm No. 2 on the south side of the 321 Building. The $321 \mathrm{C}$ Building was joined to the south wall of the 321 Building and the east wall of the 321B Building. Like the 321B Building, the 321C Building had multiple levels due to its installation over Tank Farm No 2 that had containment walls of

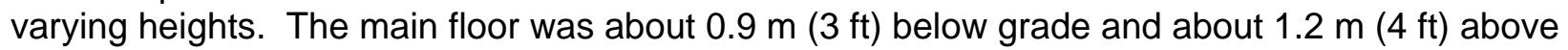
the floor of Tank Farm No. 2. Large concrete pedestals in 321C supported the three $450 \mathrm{HP}$ pumps and the 11,000 gallon horizontal storage tank for the FFTF Mockup facilities in the 321 Building.

321D Building: The 321 Building Machine Shop was modified and converted into the 321D Seismic Test Facility. The 321D Building was a metal frame, insulated panel, lean-to structure with an insulated steel roof attached to the east side of the 321 Building at the

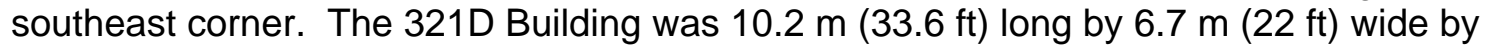

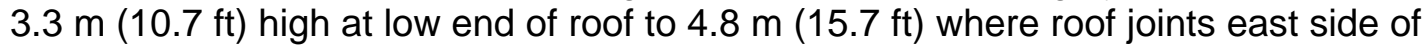
321 Building. 


\subsection{BUILDING}

Formerly the 321A Pyrochemical Building, the 323 Building was known as the Mechanical Properties Laboratory which included sodium loop test equipment. Four 25,000 gallon horizontal waste storage tanks associated with 321 Tank Farm No. 3 remain in a concrete vault below where the 323 Building stood.

Figure 3. The 323 Building was Turned Over to WCH in October 2007.

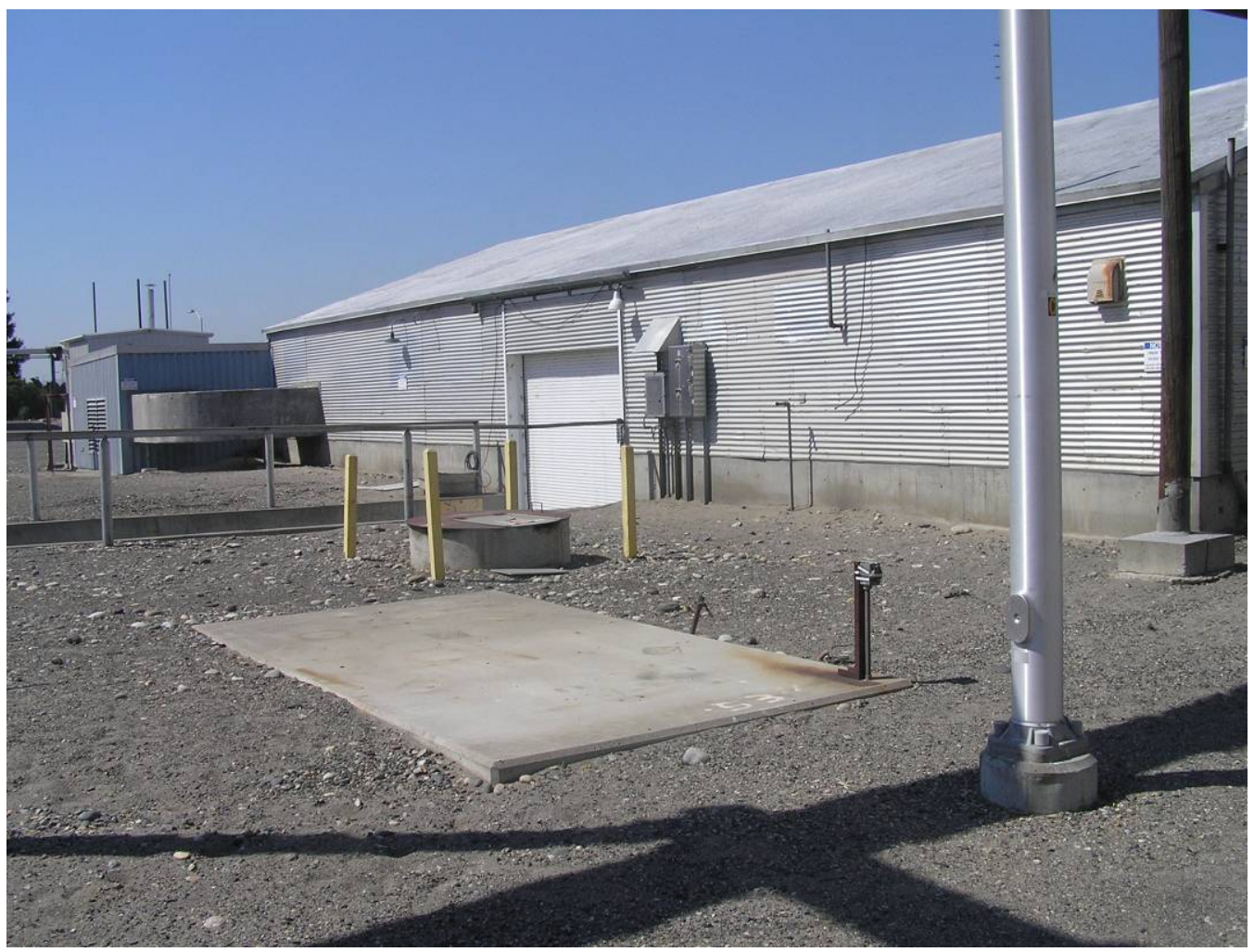

The 323 Building was an all metal building on a concrete foundation located $30.5 \mathrm{~m} \mathrm{(100 \textrm {ft } )}$ south of the 321 Building. It had overall dimensions of $24.4 \mathrm{~m} \mathrm{(80} \mathrm{ft)} \mathrm{long} \mathrm{by} 14 \mathrm{~m}(45.8 \mathrm{ft})$ wide by $4.6 \mathrm{~m}(15.1 \mathrm{ft})$ high (above grade). The south $16.8 \mathrm{~m}(55 \mathrm{ft})$ of the 323 Building was installed over a concrete vault containing waste storage tanks (321 Tank Farm No. 3). The concrete vault, which remained in-place, is $16.8 \mathrm{~m}(55 \mathrm{ft})$ long by $14 \mathrm{~m}(45.8 \mathrm{ft})$ wide by $4 \mathrm{~m}(13.1 \mathrm{ft})$ high (excluding sump); the vault roof is $1.5 \mathrm{~m}(5 \mathrm{ft})$ below grade. A $2.1 \mathrm{~m}(7 \mathrm{ft})$ high concrete wall on the outer edge of the concrete vault is the foundation for the 323 Building. A $16.8 \mathrm{~m}(55 \mathrm{ft})$ long by $1.8 \mathrm{~m}$ ( $5.8 \mathrm{ft})$ wide metal roof was added on the east side from the 323 Building roof down to the concrete foundation to enclose the remaining area over the concrete vault. The lower area of the 323 Building is $16.8 \mathrm{~m}$ (55 ft) long by $14 \mathrm{~m}(45.8 \mathrm{ft})$ wide (i.e., the concrete vault roof is the floor of the lower level of 323). The upper north end of the 323 Building is $7.6 \mathrm{~m}$ (25 ft) long

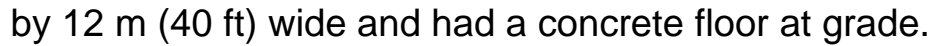




\section{$2.3 \quad 332$ BUILDING}

The 332 Building was known as the Hazardous Waste Interim Holding Facility and Packaging Test Facility. The building was constructed in the early 1980 s by Pacific Northwest Laboratories as a Class-H (unrestricted storage of flammable and explosive materials) storage building. It then became a permitted less-than-90-day waste storage area which was closed on April 21, 1997. Its final mission was a testing facility for the U.S. Department of Transportation shipping packages.

Figure 4. The 332 Building was Turned Over for Demolition in July 2004.

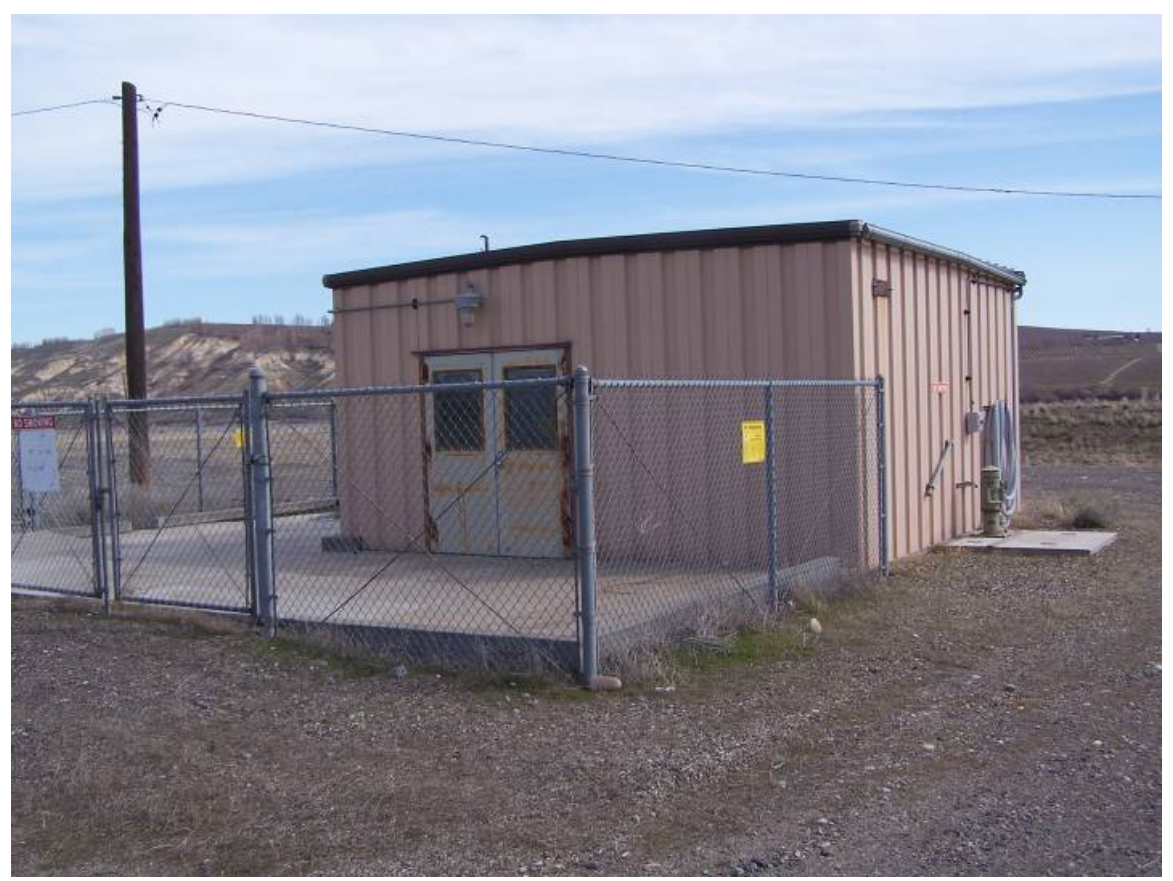

The 332 Building was a pre-engineered metal building on a $15.24 \mathrm{~cm}(6 \mathrm{in}$.) slab with footings.

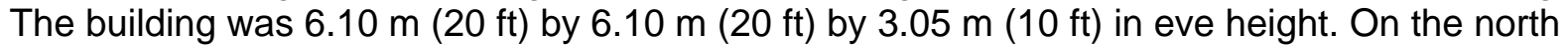
and west sides of the building was a $0.15 \mathrm{~m}(0.5 \mathrm{ft})$ thick slab with spill curbing.

\subsection{BUILDING}

The 335 Building was known as the Fast Reactor Thermal Engineering Facility and Sodium Test Facility. The 335 Building was designated as non-nuclear in its Initial Hazard Categorization $(\mathrm{IHC})$.

The original role of the 335 Building was to conduct sodium-related tests for the Fast Flux Test Facility (FFTF) development through the late 1970s. The 335 Building contained experimental equipment to study the properties of sodium and the behavior of mechanical components to be operated in a sodium environment. In reality, many of the experiments were conducted with a sodium and potassium mixture with properties very similar to pure sodium. The sodium test loops were deactivated in 1977 and removed during the 1983-1984 time period. 
The 335 Building was constructed in 1968 as a single-story, rectangular structure $30.48 \mathrm{~m}$ $(100 \mathrm{ft})$ by $18.29 \mathrm{~m}(60 \mathrm{ft})$ by $7.31 \mathrm{~m}(24 \mathrm{ft})$ high constructed on a concrete foundation with corrugated steel sides, and a corrugated steel roof topped with gravel.

A small cinder block addition was constructed on the west side of the 335 Building where the sodium test loops were stored, that was used as a "less than 90 Day Accumulation Area". There was a covered storage area on the north side of the building and two cargo shipping containers on the north-east corner of the building.

Figure 5. The 335 Building was Turned Over for Demolition in September 2005.

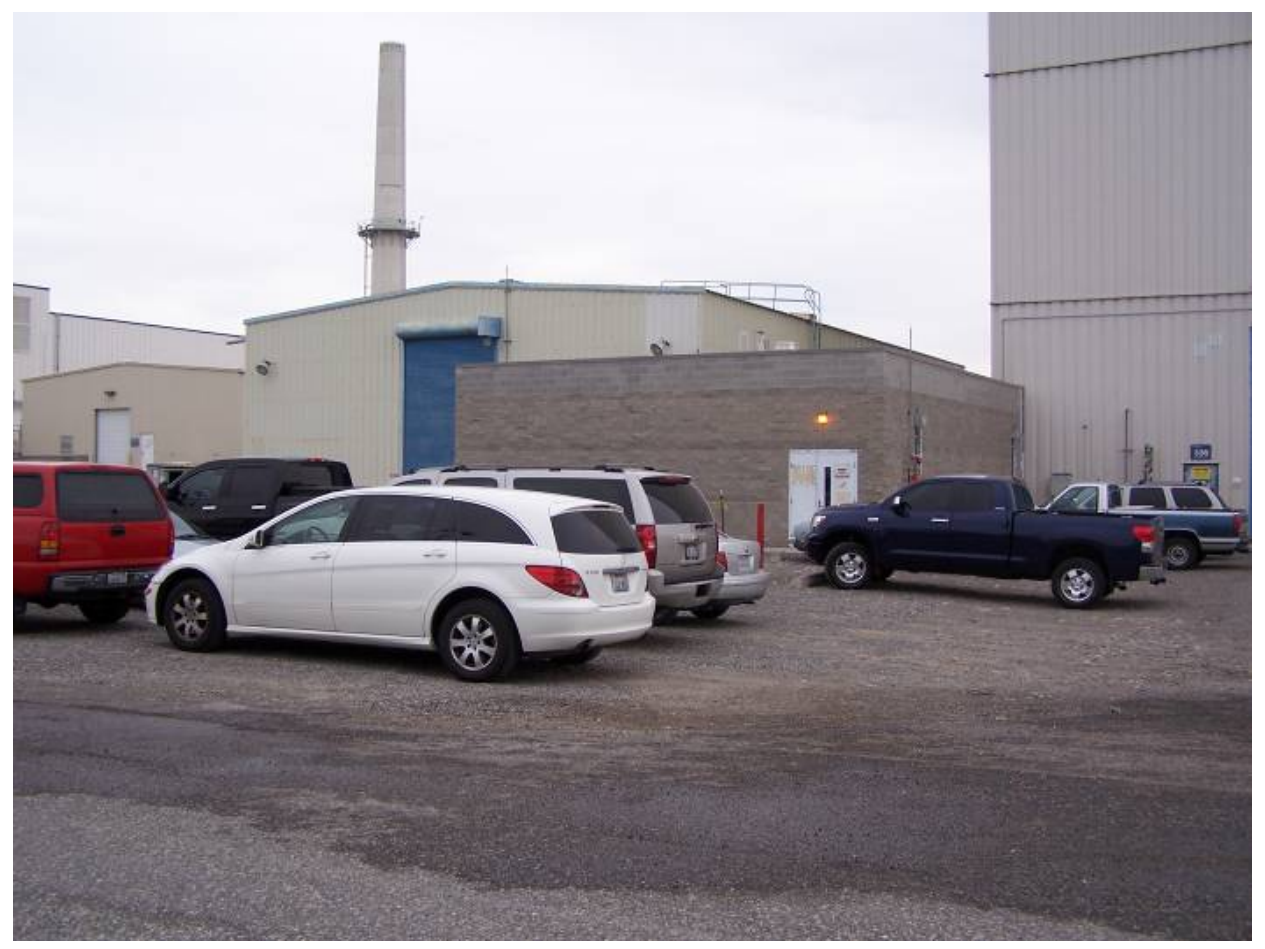

\section{$2.5 \quad 337-B A$ BUILDING}

The Boiler Annex was installed between August 1997 and March 1998 to provide steam to the 337 Building. It was constructed to replace the steam provided by the 384 Powerhouse as part of the Energy Savings Performance Contract Project in 1997.

The 337-BA Boiler Annex was a pre-engineered metal building built on a concrete slab that housed two natural-gas-fired, steam boilers. The annex contained a sump and sump pump.

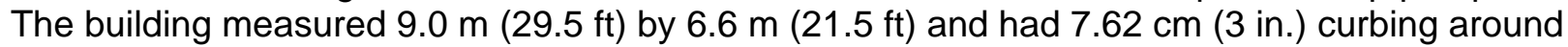
the sump and water softener. Both boilers were inactive. 
Figure 6. The 337-BA Building was Turned Over to WCH in July 2007.

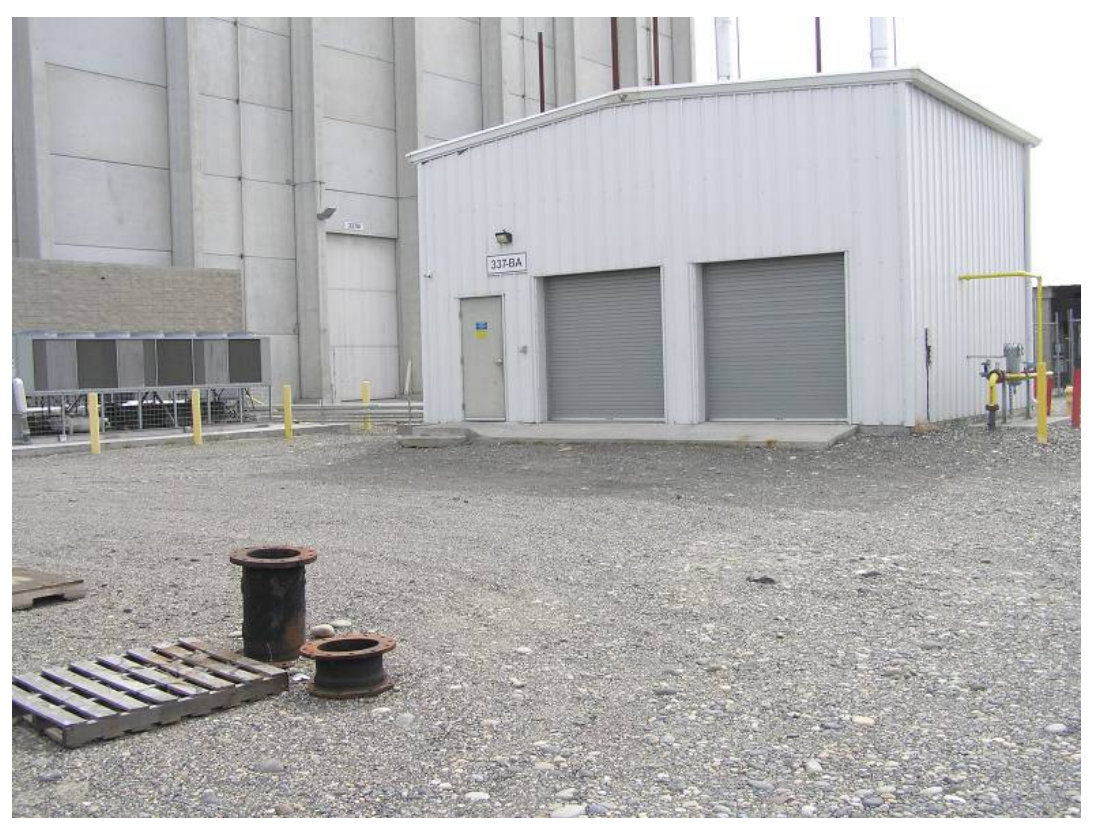

\subsection{1-66 UNDERGROUND STORAGE TANK}

The 3621-66 underground storage tank provided fuel to the back-up diesel generator for the 3621-D Building. The site is located in the eastern portion of the 300 Area approximately 146.3 $\mathrm{m}$ (480 ft) north of the intersection of the George Washington Way Extension and Cypress Street. The system consisted of a 4,000-gallon underground storage tank and the associated piping.

Figure 7. The 3621-66 Underground Storage Tank was Turned Over to WCH in August 2005.

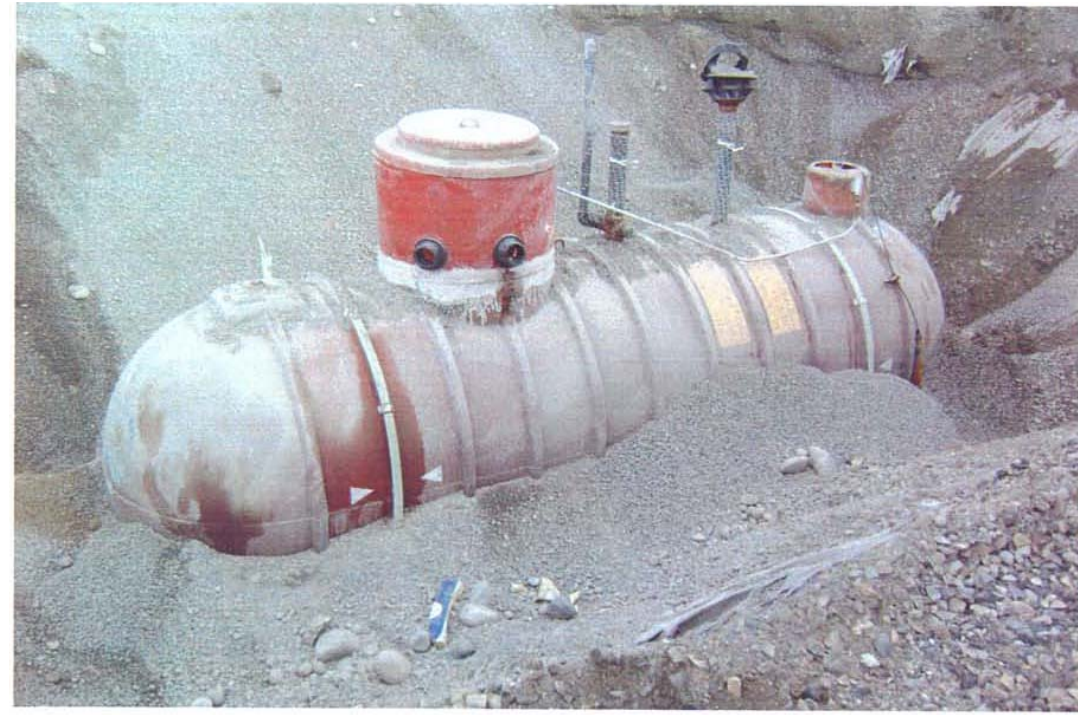

Excavated Tank 


\section{$2.7 \quad$ MO-741 TRAILER}

The MO-741 trailer was manufactured and brought to the Hanford Site in 1993 for use as office space for staff associated with the 340 facilities.

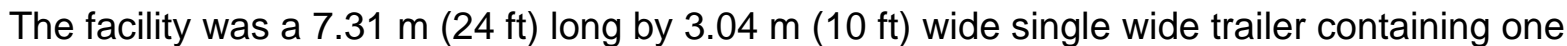
main room used as an office with no internal partition. Construction was wood framing with a sheet metal exterior. The office space was vinyl paneled with carpet flooring. The roof was sheet metal. The unit was skirted with metal panels between the ground and the structure.

Figure 8. The MO-741 Mobile Building was Turned Over to WCH for Demolition in September 2008.

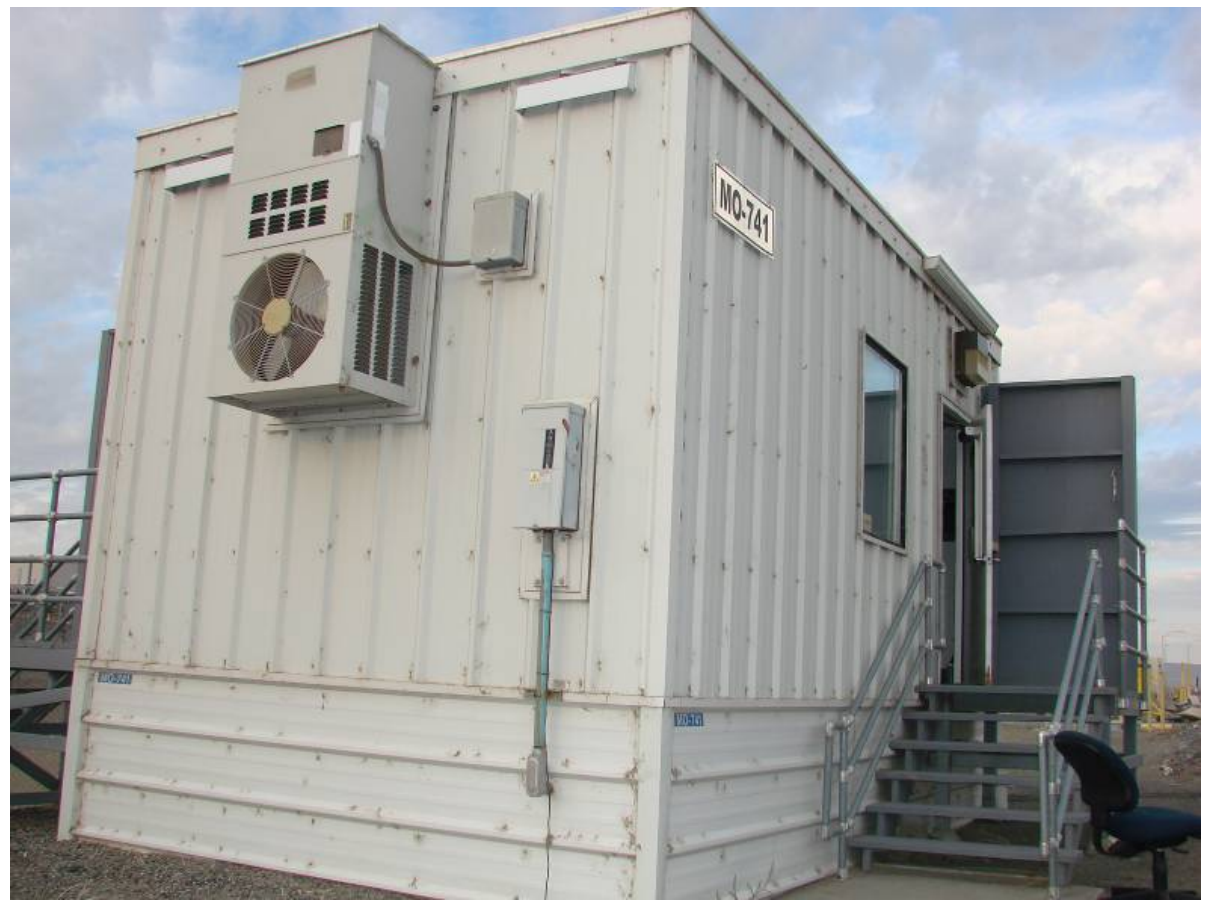




\subsection{PROJECT ACTIVITIES}

\subsection{ENGINEERING AND PERMITS}

The Removal Action Work Plan for 300 Area Facilities (DOE-RL 2007) was prepared to satisfy the requirements of the action memoranda \#1 and \#3 (EPA and DOE 2005; 2006), outlining how compliance with, and enforcement of, applicable regulations will be achieved for cleanup of 300 Area facilities. Additionally, the removal action work plan (DOE-RL 2007) and environmental control plan (WCH 2009) serve as the decommissioning plan and project management plan for the 300 Area project. The removal action work plan was prepared in accordance with Section 7.2.4 of the Hanford Federal Facility Agreement and Consent Order (Tri-Party Agreement) (Ecology et al. 1989) and was approved by the DOE, Richland Operations Office and the regulators.

Plant Forces Work Reviews were prepared for the demolition of the seven facilities to determine whether Davis-Bacon Act of 1931 prevailing wage rates for the work were applicable. Table 1 summarizes the reviews performed. The D4 work on all seven facilities was determined to be "not applicable" and the work was performed by plant forces.

Table 1. Plant Forces Work Reviews.

\begin{tabular}{|l|c|l|}
\hline \multicolumn{1}{|c|}{ Building } & PFWR Number & \multicolumn{1}{|c|}{ PFWR Title } \\
\hline 321, 323(321A, 337-BA & $8850-059-06$, Rev. 1 & $\begin{array}{l}\text { Demolition of Various 300 Area } \\
\text { Buildings }\end{array}$ \\
\hline 332,335, MO-741 & $8850-027-0$, Rev. 0 & Demolition of 300 Area Buildings \\
\hline $3621-66$ & $8850-003-08$, Rev. 0 & $\begin{array}{l}\text { Remove Abandoned Underground Fuel } \\
\text { Tank }\end{array}$ \\
\hline
\end{tabular}

Criticality screenings for the facilities were performed where required by the IHC. These criticality evaluations showed that fissionable material inventories did not exceed threshold activity values and no criticality safety requirements or controls were needed for the buildings. In addition, all the facilities were either non-nuclear or below the Category 3 threshold quantity as defined in Table A.1 of DOE Standard - Hazard Categorization and Accident Analysis Techniques for Compliance with DOE Order 5480.23, Nuclear Safety Analysis Reports (DOE-STD-1027-92, Change Notice No. 1 [DOE 1997]). When D4 work began in the buildings, some standard industrial hazardous substances remained in the buildings (e.g., polychlorinated biphenyls [PCBs]), lead paint, mercury, Freon, asbestos, beryllium). The quantity of these nonradioactive hazardous substances also did not exceed the threshold quantities ("Threshold quantities" as defined in 20 Code of Federal Regulations 1910.119 or 40 CFR 68.130). Table 2 identifies the facilities and associated IHC documents for each. 
Table 2. Initial Hazard Categorization Evaluations and Results.

\begin{tabular}{|l|l|l|}
\hline \multicolumn{1}{|c|}{ Facility } & \multicolumn{1}{|c|}{ IHC Number } & \multicolumn{1}{c|}{ IHC Category } \\
\hline 321 Complex, 323 & IHC-2006-0022, Rev. 1 & Below Category 3 \\
\hline 332 & IHC-2005-0031, Rev. 1 & Below Category 3 \\
\hline 335, 337BA, 3621-66, MO-741 & IHC-2006-0017, Rev. 1 & Non-Nuclear \\
\hline
\end{tabular}

$\mathrm{IHC}=$ Initial Hazard Categorization

\subsection{HAZARDOUS MATERIAL REMOVAL}

The scope of the demolition project included removing and properly disposing of hazardous materials (e.g., oils, grease, asbestos-containing material, mercury, lead, and PCBs). All known hazardous materials were removed from inside and outside of the buildings prior to demolition. In most cases, some Class II non-friable asbestos containing material (e.g., roofing material, floor tile, and vinyl sheeting) was left in place and removed during the demolition phase of the project. In these cases, all building demolition waste was treated as asbestos waste, and controls to minimize asbestos fiber release (e.g., fixatives, wet methods, and air monitoring) were used throughout the demolition process.

Beryllium-contaminated equipment, including high-efficiency particulate air filters and duct work, were of particular concern in those buildings that were beryllium listed. These items were thoroughly characterized prior to removal, and work control methods to minimize airborne beryllium particulate (e.g., fixatives, wet methods, air monitoring, and hygiene practices) were implemented throughout the decommissioning and demolition process.

\subsection{UTILITY AND DRAIN ISOLATION}

Once the utilities were no longer needed in the building (prior to hazardous materials removal), all electrical, water, and telecommunications services were disconnected from the buildings. Floor drains were inspected for mercury and then sealed to provide isolation. Sanitary sewers to the building were disconnected during early deactivation activities and all drains were grouted.

\subsection{DEMOLITION OF ABOVE-GRADE STRUCTURES}

In general, after the hazardous materials and equipment removal activities were performed and utilities isolated, the above-grade structures were ready for demolition. The building structures were demolished using excavator-mounted hydraulic shears and a bucket-and-thumb. The debris was segregated for loading and disposal. Building debris was processed and sampled until industrial hygiene monitoring confirmed that loading and unloading waste did not generate airborne beryllium. Standard Environmental Restoration Disposal Facility (ERDF) roll-on/roll-off containers with two 6-mil liners were used to package and ship debris. Beryllium controls required that a pool of containers were designated for use in the 300 Area only. These containers were part of a "closed-loop" disposal system and remain exclusively for use in the 300 Area. 


\subsection{BELOW-GRADE DEMOLITION AND SITE RESTORATION}

In general, for each building demolished (or for a given complex) a post-demolition summary report is prepared that documents the characterization and final status of the building at the completion of the D4 activities. Table 3 summarizes the as-left conditions of each facility. Slabs left in place will be removed at a later date by the D4 Closure Project or the Field Remediation Closure Project. Also summarized in Table 3 is the current site posting for each facility.

Table 3. Facility As-Left Condition Summary.

\begin{tabular}{|c|c|c|}
\hline Building & Slab/Below-Grade Condition & Site Posting \\
\hline 321 Complex & $\begin{array}{c}\text { Below-grade structure and tank } \\
\text { remain }\end{array}$ & $\begin{array}{c}\text { Contamination Area } \\
\text { Beryllium Contaminated Area } \\
\text { Inhalation Hazard }\end{array}$ \\
\hline 323 & $\begin{array}{c}\text { Below-grade concrete vault } \\
\text { containing waste storage tanks } \\
\text { remains }\end{array}$ & $\begin{array}{c}\text { Contamination Area } \\
\text { Beryllium Contaminated Area } \\
\text { Inhalation Hazard }\end{array}$ \\
\hline 332 & Removed & None \\
\hline 335 & Slab Remains & None \\
\hline $337-$ BA & Slab Remains & None \\
\hline $3621-66$ (UST) & Removed & None \\
\hline MO-741 Trailer & Not Applicable & \\
\hline
\end{tabular}

UST = underground storage tank

In addition to D4 of the seven facilities that occurred this reporting period, the following nine slabs left behind from previous D4 actions were also removed: 3718, 3718A, 3718B, 3718C, $3718 \mathrm{E}, 3718 \mathrm{E}, 3718 \mathrm{~N}, 3721$, and 3728 . The 3720 Building was demolished to slab on grade during FY07. The slab was removed during FY08, but completion of load-out of this slab occurred in FY09. 


\subsection{COST AND SCHEDULE}

The following section details start and finish dates for the major D4 activities in each of the seven facilities as well as the total labor costs. These costs do not include deactivation or surveillance and maintenance work performed by Fluor Hanford, Bechtel Hanford, Inc., and other contractors prior to turnover of the building to $\mathrm{WCH}$. They also do not include overhead or distributed costs, equipment and material costs, or incidental work performed by subcontractors.

Note that some activities began prior to the current reporting year (fiscal year 2009). Also, entries reading "NC" mean that no costs were collected or charged specifically to this activity. In the case of the 3621-66 underground storage tank (UST), a subcontractor flushed the contents of the tank and Surveillance, Maintenance and Utilities (SM\&U) removed the tank.

The total labor cost (before overhead and distributed costs) for all seven buildings was $\$ 2,087,440$.

Table 4. Cost and Schedule Summary. (2 Pages)

\begin{tabular}{|l|c|c|r|}
\hline 321 Complex & Start Date & Completion Date & \multicolumn{1}{|c|}{ Cost } \\
\hline Engineering Planning & $12 / 04 / 06$ & $05 / 19 / 08$ & $\$ 91,374$ \\
\hline Building Deactivation & $06 / 18 / 07$ & $05 / 05 / 08$ & $\$ 1,333,957$ \\
\hline $\begin{array}{l}\text { Building Demolition } \\
\text { (AG) }\end{array}$ & $06 / 03 / 08$ & $02 / 11 / 09$ & $\$ 289,011$ \\
\hline Waste Loadout (AG) & $07 / 14 / 08$ & $03 / 09 / 09$ & TOTAL \$1,887,511 \\
\hline
\end{tabular}

\begin{tabular}{|l|c|c|r|}
\hline 323 Building & Start Date & Completion Date & Cost \\
\hline Engineering Planning & $01 / 21 / 08$ & $06 / 23 / 08$ & $\$ 13,803$ \\
\hline Building Deactivation & $03 / 19 / 08$ & $04 / 21 / 08$ & $\$ 17,787$ \\
\hline $\begin{array}{l}\text { Building Demolition } \\
\text { (AG) }\end{array}$ & $06 / 26 / 08$ & $06 / 26 / 08$ & $\$ 14,523$ \\
\hline Waste Loadout (AG) & $07 / 21 / 08$ & $02 / 25 / 09$ & TOTAL \$54,429 \\
\hline
\end{tabular}

\begin{tabular}{|l|c|c|r|}
\hline 332 Building & Start Date & Completion Date & \multicolumn{1}{|c|}{ Cost } \\
\hline Engineering Planning & $03 / 30 / 09$ & $05 / 27 / 09$ & $\$ 3,926$ \\
\hline Building Deactivation & $04 / 30 / 09$ & $04 / 30 / 09$ & $\$ 13,236$ \\
\hline Building Demolition & $08 / 03 / 09$ & $08 / 10 / 09$ & $\$ 23,423$ \\
\hline Waste Loadout & $08 / 10 / 09$ & $08 / 12 / 09$ & TOTAL \$47,007 \\
\hline \multicolumn{4}{|r|}{} \\
\hline
\end{tabular}


Table 4. Cost and Schedule Summary. (2 Pages)

\begin{tabular}{|l|c|c|r|}
\hline 335 Building & Start Date & Completion Date & Cost \\
\hline Engineering Planning & $05 / 04 / 09$ & $06 / 25 / 09$ & $\$ 11,954$ \\
\hline Building Deactivation & $05 / 20 / 09$ & $06 / 09 / 09$ & $\$ 49,450$ \\
\hline $\begin{array}{l}\text { Building Demolition } \\
\text { (AG) }\end{array}$ & $06 / 23 / 09$ & $06 / 24 / 09$ & $\$ 28,437$ \\
\hline Waste Loadout (AG) & $07 / 15 / 09$ & $08 / 05 / 09$ & TOTAL \$94,971 \\
\hline \multicolumn{4}{|r|}{}
\end{tabular}

\begin{tabular}{|l|c|c|r|}
\hline 337-BA Building & Start Date & Completion Date & Cost \\
\hline Engineering Planning & $07 / 16 / 07$ & $07 / 24 / 08$ & $\$ 1,961$ \\
\hline Building Deactivation & $07 / 16 / 07$ & $07 / 19 / 07$ & $\$ 268$ \\
\hline $\begin{array}{l}\text { Building Demolition } \\
\text { (AG) }\end{array}$ & $07 / 24 / 08$ & $05 / 28 / 09$ & $\$ 467$ \\
\hline Waste Loadout (AG) & $06 / 11 / 09$ & $06 / 16 / 09$ & TOTAL \$2,733 \\
\hline \multicolumn{4}{|r|}{} \\
\hline
\end{tabular}

\begin{tabular}{|l|c|c|c|}
\hline 3621-66 UST & Start Date & Completion Date & Cost \\
\hline Engineering Planning & $07 / 21 / 08$ & $09 / 30 / 08$ & NC \\
\hline Building Deactivation & $11 / 03 / 08$ & $11 / 06 / 08$ & NC \\
\hline Building Demolition & $11 / 10 / 08$ & $12 / 09 / 08$ & NC \\
\hline Waste Loadout & $12 / 09 / 08$ & $12 / 09 / 08$ & TOTAL NC \\
\hline \multicolumn{4}{|r|}{} \\
\hline
\end{tabular}

\begin{tabular}{|l|c|c|r|}
\hline MO-741 Trailer & Start Date & Completion Date & Cost \\
\hline Engineering Planning & $10 / 01 / 08$ & $10 / 09 / 08$ & NC \\
\hline Building Deactivation & $10 / 09 / 08$ & $10 / 09 / 08$ & NC \\
\hline Building Demolition & $10 / 09 / 08$ & $10 / 09 / 08$ & TOTAL \$789 \\
\hline Waste Loadout & $10 / 20 / 08$ & $10 / 20 / 08$ & \multicolumn{2}{|c|}{ TO } \\
\hline \multicolumn{4}{|r|}{}
\end{tabular}

GRAND TOTAL $\$ 2,087,440$

AG - Above Grade Demolition

NC - No costs collected or charged specifically to this activity 


\subsection{WASTE DISPOSITION}

One of the objectives of the 300 Area D4 Project is to support recycling and waste minimization. However, beryllium and radiological contamination throughout the site will prevent most of the material and equipment from the buildings to be salvaged and/or transferred offsite. Therefore, all of the debris for buildings identified in this report was shipped to the ERDF for disposal.

Waste generated during demolition of the seven facilities and nine slabs demolished in FY09 was characterized under waste profiles and shipped to ERDF. Roll-on/roll-off boxes were used to ship the debris. The total number of these shipments ("cans"), tons of debris disposed of in ERDF, and the profiles used are listed in Table 5.

Table 5. Waste Transferred to ERDF.

\begin{tabular}{|c|c|c|c|}
\hline Facility & $\begin{array}{c}\text { Number of } \\
\text { Shipments }\end{array}$ & Tons & Waste Profile(s) \\
\cline { 1 - 2 } $\begin{array}{c}\text { 321 } \\
\text { 321B } \\
\text { 321C }\end{array}$ & 287 & 2030 & 300LSF001 REV 1 \\
321D & & REV 2 \\
REV 3
\end{tabular}




\subsection{OCCUPATIONAL EXPOSURES}

\subsection{PERSONNEL INJURIES}

Washington Closure Hanford personnel worked a total of approximately 700,000 hours (manual and non-manual, including subcontractors) on the 300 Area D4 project with 2 Occupational Safety and Health Administration recordable injuries and 1 lost workday case.

\subsection{PERSONNEL RADIOLOGICAL EXPOSURES}

Of the seven 300 Area facilities discussed in this report, no clothing or skin contamination incidents occurred during D4. In addition, the "as low as reasonably achievable" goal of zero person-mrem was achieved. All boundary air sample results were below procedural action levels for the duration of the project. 


\subsection{REFERENCES}

20 CFR 1910, "Occupational Safety and Health Standards," Code of Federal Regulations, as amended.

40 CFR 68, "Chemical Accident Prevention Provisions," Code of Federal Regulations, as amended.

Davis-Bacon Act of 1931, 40 U.S.C. $276 a$, et seq.

DOE, 1997, DOE Standard - Hazard Categorization and Accident Analysis Techniques for Compliance with DOE Order 5480.23, Nuclear Safety Analysis Reports, DOE-STD-1027-92, Change Notice No. 1, U.S. Department of Energy, Washington, D.C.

DOE-RL, 2007, Removal Action Work Plan for 300 Area Facilities, DOE/RL-2004-77, Rev. 2, U.S. Department of Energy, Richland Operations Office, Richland, Washington.

Ecology, EPA, and DOE, 1989, Hanford Federal Facility Agreement and Consent Order, 2 vols., as amended, Washington State Department of Ecology, U.S. Environmental Protection Agency, and U.S. Department of Energy, Olympia, Washington.

EPA and DOE, 2005, Action Memorandum \#1 for the 300 Area Facilities, CCN 0071781 , U.S. Environmental Protection Agency and U.S. Department of Energy, Richland Operations Office, Richland, Washington.

EPA and DOE, 2006, Action Memorandum \#3 for the 300 Area Facilities, CCN 118781, U.S. Environmental Protection Agency and U.S. Department of Energy, Richland Operations Office, Richland, Washington.

WCH, 2008, 300 Area D4 Project Fiscal Year 2008 Building Completion Report, WCH-310, Rev. 0, Washington Closure Hanford, Richland, Washington.

WCH, 2009, 300 Area Facilities D4 Environmental Control Plan, WCH-84, Rev. 1, Washington Closure Hanford, Richland, Washington. 


\section{DISTRIBUTION}

U.S. Department of Energy

Richland Operations Office

R. F. Guercia

A3-04

Washington Closure Hanford

K. J. Koegler

L7-11

L. M. Douglas

L7-10

D. A. Elkins

L1-07

D. J. McBride

L7-11

B. D. Smith

L7-11

G. B. Snow

L7-11

Document Control

$\mathrm{H} 4-11$

DOE-RL Public Reading Room

$\mathrm{H} 2-53$

Hanford Technical Library

P8-55 